\title{
Cost accounting and pricing improvement at Helmond Print: using Xeikon digital colour printing equipment: a case study
}

Citation for published version (APA):

Vergauwen, P. G. M. C., Busser, K., Rongen, P., Verwaijen, R., \& Vossen, D. J. L. H. (2001). Cost accounting and pricing improvement at Helmond Print: using Xeikon digital colour printing equipment: a case study. METEOR, Maastricht University School of Business and Economics. METEOR Research Memorandum No. 028 https://doi.org/10.26481/umamet.2001028

Document status and date:

Published: 01/01/2001

DOI:

10.26481/umamet.2001028

Document Version:

Publisher's PDF, also known as Version of record

Please check the document version of this publication:

- A submitted manuscript is the version of the article upon submission and before peer-review. There can be important differences between the submitted version and the official published version of record.

People interested in the research are advised to contact the author for the final version of the publication, or visit the DOI to the publisher's website.

- The final author version and the galley proof are versions of the publication after peer review.

- The final published version features the final layout of the paper including the volume, issue and page numbers.

Link to publication

\footnotetext{
General rights rights.

- You may freely distribute the URL identifying the publication in the public portal. please follow below link for the End User Agreement:

www.umlib.nl/taverne-license

Take down policy

If you believe that this document breaches copyright please contact us at:

repository@maastrichtuniversity.nl

providing details and we will investigate your claim.
}

Copyright and moral rights for the publications made accessible in the public portal are retained by the authors and/or other copyright owners and it is a condition of accessing publications that users recognise and abide by the legal requirements associated with these

- Users may download and print one copy of any publication from the public portal for the purpose of private study or research.

- You may not further distribute the material or use it for any profit-making activity or commercial gain

If the publication is distributed under the terms of Article $25 \mathrm{fa}$ of the Dutch Copyright Act, indicated by the "Taverne" license above, 


\section{Cost Accounting and Pricing Improvement at Helmond Print: \\ Using Xeikon Digital Colour \\ Printing Equipment \\ - A Case Study -}

\section{March, 2001}

\author{
Dr. Philip G.M.C. Vergauwen \\ Assistant Professor, Universiteit Maastricht,
} Maastricht Accounting Research \& Education Center

(MARC),

Accounting \& Auditing Section

P.O. Box 616

6200 MD Maastricht (The Netherlands)

(tel. ++(31)43-3883681

(e-mail: p.vergauwen@ berfin.unimaas.nl)

$\&$

K. Busser, P. Rongen*, R. Verwaijen* \&

D. Vossen*

Student-Assistants, Universiteit Maastricht,

Accounting \& Auditing Section

\section{ABSTRACT}

Helmond Print B.V., a (fictional) Dutch print provider, is facing competitive problems. The student is expected to step into the role of an independent expert advising Helmond Print's owner and manager. The first objective is to let the student find out, from a piece of qualitative and quantitative information about Xeikon N.V. machines, that the cost structure is much different than currently assumed. The student should try to improve the cost calculations, which will require linear and both non-linear

\footnotetext{
* Pacal Rongen, Robert Verwaijen and Dennis Vossen were, at the time of writing the case, student-assistants at the Universiteit Maastricht, Accounting \& Auditing Section. I am extremely grateful to Robert Verwaijen for his help and useful comments while writing the case. I owe many thanks to Pascal Rongen and Dennis Vossen for preparing and discussing the answer key(s).
}

regression analysis. A second objective is to make the student realize that the incorrect cost calculations affected Helmond Print's pricing policy and may have lead to the competitive problems faced now. The student should therefore link their investigations to pricing, search for the weak spots in the current pricing policy and make suggestions for improvement.

(Note: a solution to the case can be obtained by simple request)

\section{Background information 1}

Mr. Bertrand is the owner and manager of a company in Helmond ${ }^{2}$ (The Netherlands), called Helmond Print B.V. This company provides on-demand printing services to different kinds of customers. Various definitions for the term "printing on demand" go around, yet it is pretty self-explanatory: printing when a customer needs it. To put it more formally: the production and distribution of publication and commercial print products in quantities and cycle times based upon actual end-user demand. This definition is more market-demand-focused rather than production-demand-focused. The run-lengths tend to closely track end-user demand. This then results in a decline in order size and increase in order frequency.

When digital colour printing was introduced in 1994, it was positioned to compete with normal offset printing. This was not very successful, due to a cost disadvantage of digital

\footnotetext{
${ }^{1}$ This information on is based on the report "Digital Colour Production Printing: Cost and Productivity Benchmarks" by Strategies on Demand $®$, Prepared for Xeikon N.V., October 17, 1998 and on the internet: www.xeikon.be.

${ }^{2}$ There exists no such company in Helmond (The Netherlands). The data are taken from or based on typical production cost data of smaller printing companies in he Netherlands.
} 
Cost Accounting and Pricing Improvement at Helmond Print: Using Xeikon Digital Colour Printing Equipment

- A Case Study -

printing. More and more, manufacturers have taken the variable printing technology as an advantage, and used it for very personalised orders. As buyers increasingly turn to shorter runs and one-to-one personalised communications, on-demand printing is emerging as a viable alternative to conventional offset printing to secure a growing share of the overall printing market.

For the production of prints, Helmond Print uses Xeikon digital printing equipment. Xeikon N.V. is a young, stocklisted company (since 1996 on the Nasdaq Stock Exchange, New York) in the printing market. It is a Belgian company founded by Agfa-Gevaert and is based in Mortsel. Since its foundation in 1988 it has become the pioneer and leader in its field, being the print on demand market. What started as an independent privately held spin-off company is now a full-grown public company. It develops and makes digital colour presses for the professional market. It is within the digital colour printing market where Xeikon is the pioneer and leader in press installations, innovations, and progressive pricing policies.

\section{The current situation}

The products printed at Helmond Print fall into 4 categories: postcards, datasheets, brochures and catalogues. In order to calculate the cost prices of different order sizes, Mr. Bertrand uses the data in exhibit 1. Mr. Bertrand has to pay wages of $\$ 12$ per hour in order to be sure of his operating personnel.
To calculate the price he charges for an order, Mr. Bertrand marks up the cost price he calculated by a percentage of $20 \%$, which he believes is appropriate.

Recently, Mr. Bertrand has been worrying about two things. First of all, Helmond print has lost a number of customers over the last few months. These customers did not accept the prices Mr. Bertrand calculated and indicated to them, and some of them made a remark about the price being too high compared to other print providers. Furthermore, one of Mr. Bertrand's major competitors, Bakel Prin ${ }^{3}$, does not seem to have these problems at all. Mr. Bertrand also heard some rumours that Bakel print obtained detailed cost data on printing machines via Xeikon, which also supplies Bakel print with its printing equipment. He wonders if there could be a connection.

You, being an independent financial advisor, have been consulted by Mr. Bertrand and you are investigating these issues. First of all, you contacted Xeikon about the cost data. It turns out that an independent firm has recently researched the cost competitive position of Xeikon, comparing Xeikon's digital equipment to more conventional offset presses. Since the results of this piece of research are very favourable for Xeikon, a copy of the cost-data can be ordered by all print providers using Xeikon equipment. You decide to order the information from Xeikon and see if it is of any use. 


\section{Xeikon data}

Receiving this Xeikon information $\frac{1}{4}$ you notice that the first part deals with a description of the way the total cost of a print job is built up (see exhibit 2). The next part of the report concerns Xeikon total cost per impression data, for different kinds of products that can be printed on Xeikon machines. You are slightly disappointed by the fact that only total costs are given, without any further division (see exhibit 3).

\section{Case requirements}

Despite the problems mentioned, how would the recently acquired Xeikon data change your view on the cost calculations and price setting as they are currently in use at Helmond Print B.V.?

Does it suffice to just run multiple linear regressions? Discuss - from an economic point of view- both validity and plausibility of nonlinear approximations.

\footnotetext{
${ }^{3}$ Again, there exists no such company.

${ }^{4}$ The description is based on the report "Digital Colour Production Printing: Cost and Productivity Benchmarks" by Strategies on Demand ${ }^{\circledR}$, Prepared for Xeikon N.V., October 17, 1998
} 
Cost Accounting and Pricing Improvement at Helmond Print: Using Xeikon Digital Colour Printing Equipment

- A Case Study -

\section{EXHIBIT 1}

\begin{tabular}{|l|l|c|c|c|c|}
\hline & & Postcards & Datasheets & Brochures & Catalogs \\
\hline Number of A3 per product & & 0,5 & 1 & 4 & 14 \\
\hline Constant labour costs & $\$ 78$ per order & & & & \\
\hline Variable labour costs & & $\$ 0,007$ & $\$ 0,053$ & $\$ 0,178$ & $\$ 1,572$ \\
\hline Variable materials costs & $\$ 0,024$ per A3 impression & $\$ 0,012$ & $\$ 0,024$ & $\$ 0,096$ & $\$ 0,336$ \\
\hline
\end{tabular}

\section{EXHIBIT 2}

The total time of each printing operation includes the following elements:

- Make-ready time. Make-ready time includes the time necessary for things such as stock changes, form-size changes, plate changes (including on-press plate imaging) and blanket wash-ups.

- Start-up time. During the time used for the start-up, the press is adjusted for the proper register and colour.

- Run time. The run includes any necessary stops for reloading of paper, removal of printed product and quality or runability problems.

In non-perfecting sheet-fed presses such as the Heidelberg Quick-master DI, a multi-page print job will require multiple make-readies, start-ups, and runs. In contrast, the Xeikon presses are perfecting, with electronic collation, allowing an entire print job to be completed in one make-ready/start-up/run cycle. Prior to commencement of the printing operation itself, conventional offset presses such as the Heidelberg Speed-master 52 require the delivery of the plates required for the initial form from preliminary and platemaking area.

The total cost per impression reflects the run-length invariant costs of make-ready and start-up at low order quantities. At higher quantities the cost per impression approaches a limit proportional to the fixed component of direct costs divided by the actual run speed, plus the variable component.

\section{EXHIBIT 3}

\begin{tabular}{|c|c|c|c|}
\hline Postcards & $0,5 \mathrm{A3}$ & Datasheets & $1 \mathrm{A3}$ \\
\hline Order size & Cost per A3 impression & Order size & Cost per A3 impression \\
\hline 250 & fl 0,3670 & 250 & fl 0,3234 \\
\hline 500 & fl 0,2228 & 500 & fl 0,1748 \\
\hline 750 & $\mathrm{fl} 0,1677$ & 750 & $\mathrm{fl} 0,1407$ \\
\hline 1.000 & fl 0,1398 & 1.000 & fl 0,1187 \\
\hline 1.250 & fl 0,1198 & 1.250 & fl 0,1111 \\
\hline 1.500 & fl 0,1094 & 1.500 & fl 0,0999 \\
\hline 1.750 & $\mathrm{fl} 0,1046$ & 1.750 & fl 0,0979 \\
\hline 2.000 & fl 0,0966 & 2.000 & fl 0,0903 \\
\hline 2.250 & fl 0,0902 & 2.250 & fl 0,0920 \\
\hline 2.500 & fl 0,0882 & 2.500 & fl 0,0859 \\
\hline 2.750 & fl 0,0822 & 2.750 & fl 0,0815 \\
\hline 3.000 & fl 0,0802 & 3.000 & $\mathrm{fl} 0,0778$ \\
\hline
\end{tabular}


Cost Accounting and Pricing Improvement at Helmond Print: Using Xeikon Digital Colour Printing Equipment

- A Case Study -

\begin{tabular}{|c|c|c|c|}
\hline Brochures & $4 \mathrm{A3}$ & Catalogues & $14 \mathrm{A3}$ \\
\hline Order size & Cost per A3 impression & Order size & Cost per A3 impression \\
\hline 250 & fl 0,1220 & 250 & fl 0,1406 \\
\hline 500 & fl 0,0818 & 500 & fl 0,1237 \\
\hline 750 & fl 0,0649 & 750 & fl 0,1182 \\
\hline 1.000 & fl 0,0635 & 1.000 & fl 0,1251 \\
\hline 1.250 & fl 0,0593 & 1.250 & fl 0,1199 \\
\hline 1.500 & fl 0,0550 & 1.500 & fl 0,1194 \\
\hline 1.750 & fl 0,0556 & 1.750 & fl 0,1155 \\
\hline 2.000 & fl 0,0526 & 2.000 & fl 0,1128 \\
\hline 2.250 & fl 0,0504 & 2.250 & fl 0,1141 \\
\hline 2.500 & fl 0,0514 & 2.500 & fl 0,1134 \\
\hline 2.750 & fl 0,0505 & 2.750 & fl 0,1138 \\
\hline 3.000 & fl 0,0485 & 3.000 & fl 0,1100 \\
\hline
\end{tabular}

In calculating these cost data, wages for operating personnel are assumed to be equal to the industry average of $\$ 10$ per hour. Material costs are assumed to be equal to $\$ 0,024$ per A3 impression. 